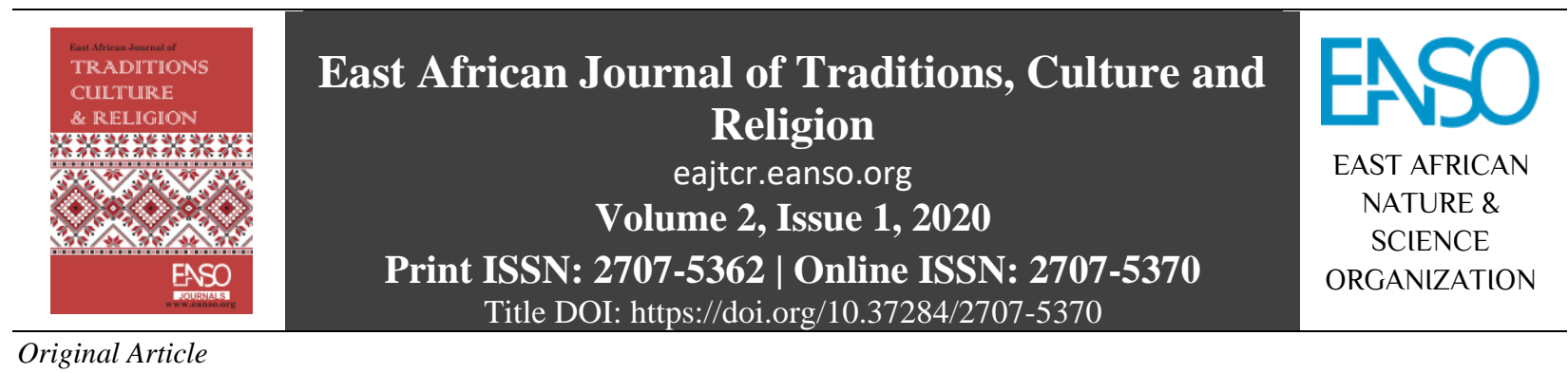

\title{
The Burden of Childlessness to Luo Women in Kenya
}

\author{
Ephraim Otieno Ochieng ${ }^{\text {* }}$ \\ ${ }^{1}$ Department of History, Religion and Philosophy; Jaramogi Oginga Odinga University of Science and Technology, Kenya. \\ *Correspondence Email: ephyochi@gmail.com \\ * ORCID: https://orcid.org/0000-0002-2083-4200
}

Article DOI: https://doi.org/10.37284/eajtcr.2.1.147

Date Published: ABSTRACT

04 May 2020 In the contemporary world, the issue of childbearing is a matter of choice. A couple may decide to bear children or not. However, within the Luo community,

Keywords: childbearing is an obligation that must be fulfilled by every couple; when this is

Childlessness, Luo community have on children. Children ensure the continuity of the lineage, Culture, and they ensure the immortality of the dead parents, among others. This article

Infertility, examines the burden the Luo childless women have to bear. The findings in this Luo Community, article are based on a cross-sectional field study conducted among the Catholic Kenya. Luo childless couples in Western Kenya. The Luo Catholic childless couples were sampled using snowball, the Catholic priests and catechists were purposively sampled, and, the Small Christian Community (SCC) leaders were systematically sampled. Data was collected through in-depth oral interviews and Focus Group Discussions. These generated qualitative data that was transcribed, coded, analyzed thematically and presented in a descriptive form and verbatim narratives as stated by the key informants. The findings of the study indicate that the Luo childless women face a number of challenges such as alienation, stigmatization, and ridicule, among others. These challenges affect their lives within the families and at the entire community. The study recommends that childless couples to undergo a medical examination to ascertain if they can be assisted.

\section{APA CITATION}

Ochieng', E. (2020). The Burden of Childlessness to Luo Women in Kenya. East African Journal of Traditions, Culture and Religion, 2(1), 1-12. https://doi.org/10.37284/eajtcr.2.1.147 
East African Journal of Traditions, Culture and Religion, Volume 2, Issue 1, 2020

Article DOI: https://doi.org/10.37284/eajtcr.2.1.147

CHICAGO CITATION

Ochieng', Ephraim. 2020. "The Burden of Childlessness to Luo Women in Kenya". East African Journal of Traditions, Culture and Religion 2 (1), 1-12. https://doi.org/10.37284/eajtcr.2.1.147.

HARVARD CITATION

Ochieng', E. (2020) “The Burden of Childlessness to Luo Women in Kenya”, East African Journal of Traditions, Culture and Religion, 2(1), pp. 1-12. doi: 10.37284/eajtcr.2.1.147.

\author{
IEEE CITATION \\ E. Ochieng', "The Burden of Childlessness to Luo Women in Kenya”, EAJTCR, vol. 2, no. 1, pp. 1-12, May 2020.
}

\title{
MLA CITATION
}

Ochieng', Ephraim. "The Burden of Childlessness to Luo Women in Kenya". East African Journal of Traditions, Culture and Religion, Vol. 2, no. 1, May 2020, pp. 1-12, doi:10.37284/eajtcr.2.1.147.

\section{INTRODUCTION}

In most cultures of the world, children are highly valued. Morell (1994) corroborates this view explaining that motherhood is celebrated, while childlessness is abhorred. However, in some parts of the world, some people choose to be childless; Morell (1994) calls this voluntary or intentional childlessness. This could be due to a myriad of factors, some may perceive children as burdensome, while others a disruption to their marriage. This is affirmed by Kimani (2001, p. 65) who advances that: "today's families, modern or otherwise, have as their primary concern the gratification of sexual needs, with other consequences as a necessary or unnecessary bother".

Morell (1994) argues that in as much as society expects couples to have children, the burden of parenting may make some couples to be childless. She challenges the societal expectation of women to be mothers. Morell (p. 2) further notes that "those women who do not give birth, the society looks at them as selfish and irresponsible." She substantiates that women without children are ignored and sometimes looked down upon. This could be because they seem not to be adding any value in society according to the various cultures. Yang and Rosenblatt (2008) in their study among the childless couples of Korea support the above argument when they found out that even voluntary childlessness is unappreciated. Inhorn (2007), in his study among the Muslims found that childlessness is equally a challenge. Rabia (2013) corroborates this assertion citing that the challenges associated with childlessness make the affected Muslims seek various interventions to alleviate the problem.

In the African communities, marriage is basically meant to bring forth offsprings. This is why childless marriages are not appreciated. According to Kimani (2001), such marriages could sometimes be voided. Mbiti (1999) supports this argument stating that lack of offspring distorts and disorients the very existence of an African and the entire community. This is because the African ontology depends on the fecundity of the living. It dictates the present and future of the community. Kimani (2001), in the same vein, argues that Africans procreate to ensure continuity of the community. According to Kenyatta (1970), childbearing is a duty that must be fulfilled by every African.

Among the Luo of Kenya, childbearing is a major component of marriage. It is the duty of every member of the community to participate in this; otherwise they face serious challenges. Mboya (2001) cites that some of these challenges follow an individual even after death. Such people who don't have offspring call for elaborate death rituals to ward off their spirits. It is evident from the above discussion that childlessness is associated with many challenges. These are especially experienced by couples who come from a background that does not appreciate childlessness.

\section{METHODOLOGY}

The findings for this article are part of a crosssectional study conducted from October 2011 to February 2014 among the Luo Catholic childless couples in Kisumu diocese, Kenya. The target population was Catholic childless couples, Priests, Catechists and Small Christian Community (SCC) 
leaders. Samples were drawn from these target groups using snowball for childless couples, purposive for priests and catechists, and, systematic sampling for SCC leaders. Data was collected through in-depth oral interviews and Focus Group Discussions (FGDs). This generated qualitative data that was transcribed, coded, analyzed thematically and presented in a descriptive form and verbatim narratives.

\section{Ethical Considerations in the Study}

The consent of the respondents was sought before being interviewed and they signed a consent form. The information given by the respondents was emotive and confidential; therefore, it was handled discreetly without breaching confidentiality. In this regard, the real names of those interviewed were not used. This is aimed at concealing their identity to avoid any embarrassment that may be caused by the information they gave.

\section{Theoretical Perspectives on the burden of Childlessness}

Morell (1994) conducted her study in the United States of America among women who chose to remain childless. According to her, she denies that childlessness can be burdening because couples voluntarily choose. Laurie (1999) equally wanted to remove the stigma of childlessness that is often put on women. She argues that childless women have been in existence since olden days, and some are part of a respectable cultural tradition that includes biblical matriarchs, celibate saints and the nineteenth-century social reformers. However, she, admits that being childless is complicated in nature accompanied by pain. Both scholars justify childlessness; therefore, childlessness should not be a challenging phenomenon because it is voluntary. Schoech (2012) equally supports that those who have chosen to be without children are happy and they do not view it as burdensome.

It is observed that in Africa, women carry the burden of infertility such as stigmatization, marital instability, abandonment, abuse and various accusations (Mariano, 2004; Dyer, 2007; Hollos, Larsen, Obono \& Whitehouse, 2009; and Isioma, 2009). Mariano (2004) narrates how a woman who dies without giving birth is buried with many rituals. The barren woman is socially isolated and becomes non-participant to nativity rituals. According to Hollos et al. (2009), if a woman fails to give birth, divorce inevitably follows. The Ijo widows had the residential right only through their sons or else they were ordered back to the paternal homes; there they would be accorded demeaning burial rites. They also cite that such women do not enter the stage of a mature woman. This is because initiation rituals are performed on the seventh month of the first pregnancy.

Mariano (2004), in his work about involuntary childlessness among the Shangana of Mozambique cites that childlessness causes a lot of problems not only for the couple but to the extended family and the whole community. Dyer (2007) in his research remarks that in the western societies, infertility has few cases of social consequences as compared to African societies since in the west couples decide about parenthood without interference from others. According to his findings, children in Africa confer social status to the parents; this is the reason couples desire children and women are under pressure to conceive. This makes infertility be associated with unhappiness. Majority of African people believe that children are a re-incarnation of the ancestors.

Obianuju (2009), in his research among the Igbo of Nigeria, admits that the issue of childlessness is quite sensitive yet crucial in society. He was moved by the way marriages were breaking down due to childlessness. Childlessness, he says is the major cause of breakages of marriages in Nigeria. Obianuju (2009) posits that marriage among the Igbo is indispensable and is meant for procreation. The birth of a child is important for a woman because it is a sign of motherhood. A child fulfils marriage and portrays a woman as complete. Therefore, a woman going into marriage has the issue of childlessness to battle with. A sterile woman faces a lot of rejection, humiliation, abuse and many physical and emotional traumas. She is abused by the sisters-in-law and even the motherin-law. The studies expose the challenges that childlessness brings to Nigerian women.

Chamie and Mirkin (2012) carried out their study on the effects of voluntary childlessness. They opine that voluntary childlessness keeps the fertility 
below the replacement level. Childlessness reduces the size of the future labour force and boosts the proportions of the elderly and thereby increases the old-age dependency ratio. Their study established that voluntary childlessness affects the demographic pattern, which has far-reaching implications on the domestic labour force, immigration levels, voting patterns, taxation, pension expenditure, education funding and healthcare costs. This study equally appreciates that voluntary childlessness comes with socioeconomic and political challenges. The above literature confirms that childlessness is associated with many challenges. The extent to which the challenges affect the Luo women is discussed in the next section on the study findings.

\section{FINDINGS AND DISCUSSIONS}

The study established that among the Luo, childlessness is not desired. A key informant observed that due to the societal expectation that a couple needs to bear children, some women fake pregnancy by stuffing clothes in their stomach, and later on they steal children (Oral Interview on 27/3/2012). This is corroborated by Odiwuor (2019) who reported that in Homabay (Kenya), a woman buried two dolls after having left home for delivery at the County Referral Hospital. Investigations established that she feigned pregnancy.

Field data revealed that childlessness is burdening to women in the Luo community compared to men. This is supported by Rabia (2013) who submits that among the Muslims, childlessness is considered to be a woman's problem. Childless women suffer a great deal in many aspects. The study exposed how one childless woman suffered greatly. In tears, she had the following to say:

The fact that I could not give birth brought a lot of problems. My husband continuously blamed me and could occasionally talk about it when we had quarrelled. He continued to scold me about it every now and again (Oral interview on $23 / 1 / 2012$ ).

She observed that it is important for a woman to have her own child since it gives one the courage to talk even amidst other women. The child even gives one a name in the village. The sufferings that she underwent were not unique to her only. Majority of women attested to this and indicated that being unable to bear children affected their lives a great deal. Another woman supported this saying:

There is no Luo who would want to marry without a child. Childlessness is something so serious that one would try so hard to overcome. When it comes to the issue of a child, one can do anything, even the indigenous ways. At that time, one cannot think of other things; even one can forget about the Christian teachings (Oral interview, 23/1/2012).

The above result that infertile women suffer a great deal is supported by Inhorn and Curtin (2012) that childless women in the Middle East face ridicule and social ostracism and that they may be accused of casting an 'evil eye' on other women's children due to envy. Similarly, Rabia (2013) maintains that infertile women are viewed as a potential source of harm to the children of others; thus, they are avoided and excluded from social events. Achebe (1958, p. 54) confirmed this when he said, "The birth of children in the traditional African societies should be a woman's crowning glory". This is the reason why women are happy at childbirth; in it, they see their success and progress. This is again supported by Mariano (2008) when he submits that a woman who has not given birth is considered incomplete because she has not fulfilled all the life stages from childhood to adulthood.

Childlessness is challenging because it is a reality which is against the normal expectation of the community; the SCC leaders observed the following challenges that some childless women face: some are abused by their relatives, while others also despised and ridiculed. Some of these come from the mothers-in-law and other women. It was observed from the FGDs conducted in Rang'ala Parish that some are abused that they are "filling up the toilet", instead of giving birth. Some are abused that they do not profit the home with anything. When they correct a child who makes a mistake, they are always reminded to give birth so as to quarrel their own children. The SCC leaders of Aluor Parish observed that childless women are despised by the villagers. The abuse that the infertile women undergo is not only unique to the 
Luo community. Dyer (2007), in his study of infertility among the women of South Africa, conjectures that infertile women face maltreatment and abuse.

Burnett and Panchal (2008, p. 190) commenting on the burden associated with childlessness advance: "There are stigma, anxiety, helplessness, confusion, and shame regarding their inability to have a child". Some of the women gave their own testimonies of the challenges that they personally undergo. A woman painfully shared her challenges, saying:

It is quite challenging since I have no one to help me. Inow live alone given that my husband died. Am forced to struggle on my own and whatever I get is what I live on. Sometimes there is no one that I can send. It is quite challenging I have always prayed to God to give me one or two, but there is nothing (Oral interview on 23/1/2012).

These similar sentiments were shared by two other women who described how being childless is quite heavy on them. They said that they are lonely, and even if they were unwell, there is no one to send. The same was experienced by another one who made a rejoinder that:

These challenges are so many and they make anyone to be scared of being childless. It is something that I cannot avoid, but I would not wish anyone to go through what I am experiencing (Oral interview on 30/102011).

Another couple admitted that even if they are a couple living together, but the loneliness is still there. They observed that:

The loneliness is not because one is living alone in this home, but children keep their parents company. Our home is so lonely and it feels bad. We just have nothing to do about it (Oral interview on 11/4/2013).

This experience of loneliness was also observed by the SCC leaders of Aluor who said that: "When they are unwell, they may not have anyone to help them and so this is quite challenging to them" (FGD conducted on 11/2/2012). This was corroborated by the SCC leaders of Nyabondo Parish who said that one of the challenges the childless couples face is loneliness. They said that this might be as a result of stigmatization in the society as they may not have people to associate with them.

One woman in tears had the following to share when she was asked about the challenges they faced as a childless couple. She said:

It is quite challenging being without a single child. Even if you are sick, there is no way in which you can help yourself. There is nowhere you can even get money. You know a woman of my age now gets her money from the children. My fellow women can do many things because they are being supported by their children, me I cannot do much since I have no one to help me (Oral interview on 21/11/2011).

Many women shared the same experience reporting that they have no one to help them even in performing household duties. One argued that she resorted to relying on God since she is living alone with no one to talk to because the husband died. She continued to say that it is quite a frustrating life and she finds no purpose of living too. This is the loneliness that one catechist commented on. He said that when the couples grow old, it worsens. A priest (Oral interview on 10/1/2012) supported this argument saying that there is always a worry for the future, how the future is going to be. In Luo culture, there is that aspect of the future generation. The SCC leaders observed that this aspect of the future is quite challenging since these childless couples may lack financial and other material support as they grow old.

One woman argued that being unable to conceive makes a woman to be despised not only by the community more so when the husband marries another wife and she gives birth to children. It would be easy for the co-wife also to despise the other one who is not capable of giving birth and this would make one feel bad. Another one shared her challenges of being childless. She said sadly:

One has to be troubled since your age mates are progressing and leaving you behind... Sometimes you look at the future; you see that children are the ones who help their parents. Now I just live knowing that there is no help for me even in future (Oral interview on 23/1/2012). 
This was corroborated by another catechist who said that:

Someone without a child would see that he/she has no future. When they see their peers or those they are staying with having children, they may feel so bad in their hearts. Sometimes the community may also scold and laugh at their predicament (Oral interview on $3 / 2 / 2012$ ).

Field data revealed that women suffer from social isolation. A couple observed that being childless has many challenges, especially on the part of women. The woman sadly narrated her challenge, saying:

No one can accept a woman who cannot give birth. This is why I was sent away from my first marriage, then I came and stayed with my sister before I got this man that I am now living with (Oral interview on 23/1/2012).

Another woman in tears described how she suffered isolation from her co-wife and the husband. Even the children were discouraged from going to her house because she would culturally affect them. She narrated the following:

Due to the fact that I did not have children, my co-wife had to restrict her children from coming to my house. She was advised that since I do not have children, I would affect her children and they may even die. This even made them burn my house so that I could not live close to them (Oral interview on 30/10/2011).

The above result is supported by Blackburn (2001), who says that involuntary childlessness brings loneliness and isolation to the couple. Umberson, Pudrovska, \& Reczek (2010) also associated childlessness with loneliness and depression. This is associated with lack of companions, missed experiences and lack of support and care. The same is supported by Chamie and Mirkin (2012) who argue that the aged childless couple, especially women are likely to be affected. They further note that in Italy, older childless couples lack health-care and social support. Whilst, in the United States of America, older childless couples have higher medical costs and more complex health-care needs than their counterparts with children.
Dutney (2007), in support of the above argument, declares that childlessness is quite challenging; it brings about social and cultural alienation. Those who are childless may find it difficult to perform certain cultural rites which are done specifically with the birth of a child. He observes that the couples may cut links totally with the ancestors since it is the children that link the parents with their ancestors.

This is validated by Dyer (2007) who argues that infertility results in stigmatization and isolation. $\mathrm{He}$ points out that even children are advised to avoid infertile women. Gerritts (1997) describes how women in Mozambique who had not given birth were prevented from participating from speaking during important traditions surrounding fertility and childbirth. This social alienation is not only among the Luo community but in most of the African cultures. Dyer (2007) points out how the infertile women of Nigeria are deprived of their womanhood. This is because womanhood is obtained after a clitoridectomy, which is conducted in the seventh month after pregnancy. Infertile women, therefore, will not obtain the status of a mature adult woman. Thus they are marginalized. Mariano (2008) also consents that childlessness may lead to social isolation.

Fieldman (1994) reiterates that among the Bangante people of Cameroon, without children, women struggle to cultivate the land and cannot build their support system. In addition, he says that these women face poverty without help and support from children. Hollos et al., (2009) reports the same among the women of Nigeria, only sons secure a home for a woman in her old age since her right to reside in her deceased husband's home is possible only through her male offspring.

Nwoye (2006) concurred that childlessness is not accepted in traditional African communities. He says that barrenness would make marriage unsuccessful and successful marriage is that in which children are born in. This means that according to African society, the success of a marriage is determined by the number of children brought forth. It does not matter whether the couples have a successful career, a good home or money. Basden (1966, p. 68) observes that "to be childless is the greatest calamity that can befall an 
African woman". Mbiti (1999) supports this argument remarking that all marriages in the African society are meant to bear children, and that marriage without procreation is incomplete. The study established that the reality of childlessness affects the woman since it is something that is abnormal. Every couple expects that once they are married, they should beget children. This too is the expectation of the community.

The interview findings indicated that childlessness is an experience that the majority of people dread. This is because being childless does not ensure the continuity of the family. Another woman sadly expressed how the fact that she could not bear children disturbed her tremendously. She said:

I was troubled yes since as a human being I also need to have my offspring. Thinking that I could not have my own children was quite unbearable. But I just left it to God since maybe that was his plan (Oral interview on 23/1/2012).

Another expressed her feelings with the following words:

I really feel sad that I cannot have children. Sometimes life is so lonely and before I came to terms with it, I continuously blamed God for my state. It is a terrible thing (Oral interview on 11/4/2013).

The SCC leaders of Rang'ala Parish (FGDs conducted on 6/3/2012) admitted that childlessness is not something that one could desire or even accept. They observed that majority of couples are not happy with their predicament. Mbiti (1975, p. 115) advances that: "without children, there is no concept of the family in Africa; without children, therefore, the concept of the family would grind to a halt". The same was observed by the SCC leaders from Aluor Parish (FGDs conducted on 11/2/2012). They observed that childlessness indeed was a reality that interfered deeply with the family and the clan's development. Since the family makes up the clan, the clan would be affected since there would be no growth in terms of the number of children that are born. Mbiti (1975) confirms the burden that comes with childlessness stating that, in Africa, every normal person is obliged to marry and bear children. Childlessness, therefore, is greeted with a lot of scepticism. No one would want to be childless since it is a calamity and a bad omen.

The study found out that childlessness affected most of the marriages and the lives of the couples in a very profound way. This is because among the Luo and among many other African communities, marriage is meant to bear children. The Luo community as a whole and the Luo couples would not appreciate childlessness in their marriages. Another woman described with deep pain and sorrow how her state of childlessness affected her marriage and the relationship with her co-wife. She said this:

Some people told her that since I do not have children, I will 'spoil' her children. This started to derail the harmony that we had. She started to withdraw her children from me and soon there was chaos in the home. Even my house was burnt down in the home and since then I am living in a rented house where I carry out my business (Oral interview on 30/10/2011).

Another informant emotionally and in tears recounted her story how her inability to bear children cost her marriage after a grand wedding. She said the following:

We had a very colourful wedding and I knew that my marriage would be so wonderful. After two years problems started because we did not have a child yet. My mother-in-law started to complain. The third-year I could not bear it, and we called off the marriage. Now I have built my home where I live with the three children that I adopted. I do not want issues of men and marriage anymore (Oral interview on $3 / 2 / 2012$ ).

The stories of the above informants are not strange since most childless couples are not living in peace. This was corroborated by the SCC leaders of Rang'ala Parish who confirmed that the majority of childless couples rarely live in peace. The Small Christian Community leaders observed that such couples are always in pain, sadness and loneliness. They said that some of such couples quarrel a lot and are bitter with others' children. The same was observed by the SCC of Nyabondo Parish. They said that "Childlessness brings a lot of sadness and bitterness to the affected couple" (FGD conducted 
on 11/04/2012). The same experience is observed by Blackburn (2001), who reports that childlessness may make marriages to end and some women may contemplate suicide. Ram (2006) says the same on Indian women; they suffer most and are faced with divorce, separation, dissertation or disruption of marriage and even domestic violence from the husband and the in-laws.

Sewpaul (1999), in her argument, displays that in Africa, two people enter into a marriage relationship in order that they may have children. This has the main purpose of perpetuating the clan. Therefore, if they cannot bear children, then they interfere with the ritual life of the community. Mbiti (1999) concurs with this argument saying that African marriages are meant to bear children. Mbiti (1975, p. 106) supports this, saying that: "Through marriage and childbearing, human life is preserved, propagated and perpetuated". Therefore, if the marriage of a couple is not fruitful, then the process of the perpetuation of life is profoundly interfered with. This becomes very challenging to the couple and even the community as a whole.

The study found out that there was the instability of the marriages. This was mainly caused by the man's family. The members of the family are always worried when the marriage is childless. This is the reason for them even trying to push the couple into certain remedies. Another informant had to put up with the pressure from the kinsmen of the husband. They put a lot of pressure on the husband to marry another woman because she was not able to bear children. She said:

The family and clan had a lot of problems saying many bad things and abusing me because we did not have children. I am the one whom they thought had a problem, so they put a lot of pressure on my husband to marry. But with him, he did not care about what they were saying that is the way we have lived with him to date (Oral interview on 21/11/2011).

One informant on her part painfully shared her own personal experience how the family and the clan of her husband had a lot of problems with her childlessness. She said the following:

My in-laws had a lot of problems with me. They were saying many bad things and abusing me.
The only thing that helped me and saved my marriage is that my husband told me that he is the one who married me and not his family (Oral interview on 21/11/2011).

Another woman equally described how she had lived with her husband peacefully and happily, but the family came in to interfere. She narrated this:

We lived peacefully for thirteen years without children. The family of my husband kept on complaining that their son needed to have children. They pressurized him to marry another wife to get children. When he married another woman, this affected the peaceful marriage that we had. Our relationship changed tremendously since he gave more time to the other woman and the children (Oral interview on 23/1/2012).

The above findings indicate that the family of the man is responsible for the pressure that the couples undergo. This gives the man limited options and this is a great challenge to the lives of these childless couples. The same culture is depicted in Ogola (1994, p. 30) where both the mother of Chief Owuor Kembo and the council of elders insisted that he should marry. The mother said: "My son, what if some ill-wind took your only son!" Mbiti (1999) confirms that among Africans, marriage and procreation are issues of obligation that an individual had to undergo. This obligation that each individual owes to the community is what drives the community to put pressure on an individual when there seems to be no offspring in a given marriage. Ogola (1994) presents this when she depicts the council of elders trying to convince the chief that he needed to marry another wife even if he did not want but for the sake of the community, so as to get enough heirs to guide them when he is gone.

The SCC leaders of Aluor Parish had the same observation that the couples face pressure from the parents and other friends or company. Especially the men may be pressurized to marry another wife. In some rare cases, the relatives of the woman may also pressurize her to leave the man. Similar observations were made by the catechist of Ojolla Parish and the catechist of Nyabondo Parish, they both concurred that majority of the childless couples had unstable marriages due to quarrels. Another key informant narrated her painful 
experience of how childlessness spoilt her happy marriage. The husband married her sister and later on married a third wife, after which the man abandoned them for the third wife. She said:

We live in the same house, but he is not helping my sister and me. We feed and clothe ourselves. After he married the third wife; he abandoned my sister and me. Since then, we are living in the same house, but there is no peace. We have a lot of quarrels and sometimes we do not even talk in that house (Oral interview on 23/2/2012).

In one of the FGDs with Rang'ala SCC leaders, it was reported that in some marriages where couples suffer childlessness, the unions do not survive. They end up in divorce. They also reported that some mothers-in-law could not let the son and the daughter-in-law live in peace without children. The SCC leaders of Ojolla Parish (FGDs conducted on 27/3/2012) further commented on this when they observed that childlessness might lead to divorce and marriage instability. Nwagwu (2008, p. 139) supports this argument when she observes that, "A marriage without children in Africa is regarded as incomplete and unhappy". The SCC leaders of Ojolla Parish concurred that some childless couple would be having an unstable marriage which may lead to divorce.

One priest argued that childlessness would change the perception of an individual of himself/herself. The priest said:

A man is ashamed of himself, what people think about him, that he has no manhood. One is not useful to society as such. The woman also feels that shame and guilt that she cannot conceive (Oral interview on 10/1/2012).

A catechist observed that some of them do not live in peace since they do not love one another. They quarrel every day, they accuse each as the cause of childlessness, and thus they lose trust in one another. Such accusations arise because some men find it difficult to go to the hospital and have a potency test that might open avenues for treating the disorder. Another key informant supported this view that the blame game that exists between the childless couples makes the relationship between the couples go sour. Some catechist concurred that some couples do not live in peace; they live blaming each other and the majority of the men end up marrying another woman. A similar experience that childless couples have quarrels that may even lead to breakups was observed by another priest. He said that majority of the marriages are no longer monogamous since the men would want to try from other women if they can have children. This was also confirmed by the SCC leaders of Nyabondo Parish who observed that childlessness might lead to extramarital sex.

A priest argued that one of the reasons that make the couples find it difficult to accept their state of being childless and live comfortably with it is how society perceives them. Thus the pressure from the society may create disharmony between the couples. The reason for such problems in the marriages of the couples is because the marriages have not fulfilled their main objective which is to bear children. Mbiti (1999) concurs with the above argument that childlessness caused by sterility or barrenness on the part of the wife could cause divorce. He says that marriage is complete only with the birth of the first child. A similar observation is made by Nwoye (2007) who observes that the traditional African marriages are basically teleological. These goals are to have a permanent peaceful relationship and for procreation of children. Once children are not attained as one of the goals, then there would be no peace and even the relationship may end up not being permanent. This is corroborated by Olawoyim $(1968$, p.2) who says: "One of the primary purposes of a customary marriage is to beget children".

The study revealed that the fact that other than the burden the childlessness brings to women, men who are unable to sire children among the Luo experience disappointment. One childless man described with a lot of pain and sorrow, punctuating with silence his narration, "Till now we did not try anywhere else to get a child. We are now old...it is a sad story... but, we left it for God. I have gotten used to staying like this" (Oral interview on 20/10/2011).

This is an indication that childlessness can equally affect men. Barden (2005) observes the same among the males from Malawi and Egypt. He describes infertility as humiliating, threatening and 
a profoundly emasculating experience. Infertility is quite pernicious to an African. According to Inhorn and Curtin (2012), they observe that in the Middle East, infertility affects men's personhood, marriage and even family relations. Blankson (1999, p.1) observes the same among the Yoruba who have a saying that a man's wealth is measured in part by the number of children he has and a woman's value to her husband is determined by her ability to bear children.

Findings from the field indicated that childlessness would affect even the personality of the couples. Another priest shared his pastoral experience of the childless couples. He said that couples lose selfesteem. He narrated the following:

They always feel good when being called the father of so and so or the mother of so and so. In a situation where somebody has none, he/she has no backbone; he has no roots and sometimes may not get any responsibility given in society. Others would not like these types of people to be given responsibilities. For example, if you want someone to instruct children, you would easily prefer the one with children than the one without (Oral interview on $3 / 2 / 2012$ ).

From the above argument, it is evident from the study that without children, a couple would be affected psychologically since they will have no one to call them mother or father. In turn, they are also not able to be called by the name of their children. In most of the cultures in Africa, most mothers and father are not called by their real names but by the names of their children. Mariano (2008) supported this argument when he observed that in Africa, a child is important since he/she plays an important role in the construction of the identity of the parents. The people would call them after the child, for example, the mother of so and so.

\section{CONCLUSION AND RECOMMENDATIONS}

Childlessness is burdensome to Luo women in many respects. These could be in the form of social alienation and stigmatization, loneliness, being despised, shame and guilt. Men sometimes are pressurised to marry another woman by the kinsmen. In many cases, childlessness leads to disharmony in the family. The study also revealed that the childless couple might suffer loneliness. This loneliness reaches its peak in old age and may cause great psychological distress. Childlessness comes with "immortality" problem. In Africa, children are named after their grandparents or after their ancestors. These childless couples will not have offspring to remember them.

The study made the following recommendations: Both couples should help each other in carrying the burden of childlessness; the Luo men should overcome the chauvinism which makes them blame their wives in cases of childlessness. The childless couples should visit the health facilities to establish the cause of their childlessness. Some of their problems could be addressed medically. This could also help them avoid blaming each other since they would know the cause of their childlessness. And in turn, it could help them live in peace.

\section{ACKNOWLEDGEMENT}

I would wish to acknowledge all the key informants who willingly shared the information and their experiences for this study.

\section{REFERENCES}

Achebe, C. (1958). Things Fall Apart. London: Heinemann.

Barden, O.J. (2005). Unmet fertility expectations and the perceptions of fertility problems in a Malawian village. African Journal Reproductive Health, 9, 14-25

Basden, G. T. (1966). Among the Igbos of Nigeria. London: Frank Cass and Co. Ltd.

Blackburn, K. (2001, February 4). Coping With Childlessness. The Guardian. The Observer.

Blankson, H. (1999, February 23). Childlessness and its Effects on Marriage. The Independent. Retrieved from https://allafrica.com/stories/199902230233.ht $\mathrm{ml}$ 
Burnett, J. A. (2003). Understanding the impact of infertility: Mental health considerations. Florida Psychologist, 54, 6-9.

Burnett, J.A., \& Panchal, K. (2008). Incorporating Ideological Context in Counselling Couples Experiencing Infertility. Journal of Humanistic Counselling, Education and Development. 47, 187-199.

Chamie, J., \& Mirkin, B. (2012). Childless by Choice. Yale Global. Macmillan centre. Retrieved from https://yaleglobal.yale.edu/content/childlesschoice.

Dutney, A. (2007). Religion, infertility and assisted reproductive technology. Best practice and research clinical obstetrics and Gynaecology, 21(1), 161-180.

Dyer, S.J. (2007). The Value of children in African countries - insight from studies on infertility. Journal of Psychosomatic Obstetrics and Gynaecology, 28(2), 66-79.

Fieldman, S. P. (1994). Plundered kitchens and empty wombs: Fear of infertility in the Cameroonian grassfields. Sociology of Science Medicine, 39, 463-474.

Gerrits, T. (1997). Social and cultural aspects of infertility in Mozambique. Patient Education Counselling, 31, 39-48.

Hollos, M., Larsen, V., Obono, O., \& Whitehouse, B. (2009). The problem of infertility in high fertility population: Meanings, Consequence and Coping Mechanisms in two Nigerian communities. Social science and medicine journal, 68, $2061-2068$.

Inhorn, M.C. (2007). Reproductive Disruptions: Gender, technology, and Biopolitics in the new Millennium. New York: Berghahn Books.

Inhorn, M.C., \& Curtin, Z.B. (2012). Infertility and Assisted Reproduction in the Islam Middle East: Social, Religious and Resource Consideration. OBGYN monograph, FVV, 2429.
Isioma, E. (2009). Challenges of Childless women in Nigeria. Retrieved from http://www.thetidenewsonline.com/2009/10/0 7/challenges-of-childless-women-in-nigeria/.

Kenyatta, J. (1970). Facing Mount Kenya. London: Heinemann.

Kimani, W. C. (2001). Sexuality and Marriage in Africa, In A. Bryson (Ed.), A Theology of Sexuality and Marriage. Nairobi: Uzima Press.

Laurie, L. (1999). Without Child: Challenging the Stigma of Childlessness. New York: Routledge.

Mariano, E.C. (2004). Involuntary childlessness among the Shangana (Mozambique). Journal of reproductive and infant psychology, 22 (4), 261-269.

Mbiti, J. S. (1999). African Religions and Philosophy. $2^{\text {nd }}$ ed. Oxford: Heinemann.

Mbiti, J. S. (1991). Introduction to African Religion. ( $2^{\text {nd }}$ ed.). Nairobi: East African Educational Publishers.

Mboya, P. (2001). Luo Kitgi Gi Timbegi. (J. Achieng', Trans.). Nairobi: Atai Joint Limited. (Original work published 1938).

Morell, M. (1994). Unwomanly conduct: The challenge of intentional childlessness. New York: Routledge.

Nwagwu, M. G. (2008). Religious Vows in Traditional African Context. African Ecclesial Review, 50 (5), 132-151.

Nwoye, A. (2006). A narrative approach to child and family therapy in Africa. Contemporary family therapy journal, 28 (1), 1-22.

Nwoye, A. (2007). The practice of intervention polygamy in two regions of Africa: Background, theory and techniques. Dialectical Anthropology journal, 31, 383 421.

Obianuju, C. A. (2009). Which way Nigeria (3): Childlessness in Marriages. Retrieved from http://www.nigeriavillagesquare.com/articles/ 
which-way-nigeria-3-childlessness-inmarriages.html

Odiwuor, G. (2019). Woman who buried baby dolls feigned pregnancy. Nation Online. Retrieved from https://www.nation.co.ke/counties/homabay/Woman-who-buried-baby-dolls-feignedpregnancy/3444904-51088301398x4ez/index.html .

Ogola, M. A. (1994). The River and the Source. Nairobi: Focus Publishers Limited.

Olawoyim, G. A. (1968). System of Customary Marriage Among the Ifes, Seminar. London: Institute of African Affairs.

Rabia, A. A. (2013). Infertility and Surrogacy in Islamic Society: Socio-cultural, Psychological, Ethical and Religious Dilemmas. The Open Psychology Journal, 6, 54-60.

Ram, U. (2006). Childlessness and Its Consequences in India: Level, Patterns and Differentials. India: Mumbai.

Schoech, S. (2012, April 30). For Women: The Grief of Childlessness. The Singles Place Word Press.

Sewpaul, V. (1999). Culture, religion and infertility: a South African perspective. $\mathrm{Br}$ Journal of Social Work, 29,741-754.

Umberson, D., Pudrovska, T., \& Reczek, C. (2010). Parenthood, Childlessness and Well-Being: A Life Course Perspective. Journal of Marriage and Family, 72(3), 612-629.

Yang, S., \& Rosenblatt, P. C. (2008). Confucian Family Values and Childless Couples in Southern Korea. Journal of Family Issues, 29(5), 571-591. 